\title{
Osmium-Hydride-Acetylacetonate Complexes and their Application in Acceptorless Dehydrogenative Coupling of Alcohols and Amines and for the Dehydrogenation of Cyclic Amines
}

\author{
Miguel A. Esteruelas,* Virginia Lezáun, Antonio Martínez, Montserrat Oliván, and Enrique Oñate \\ Departamento de Química Inorgánica - Instituto de Síntesis Química y Catálisis Homogénea (ISQCH) - Centro de Innova- \\ ción en Química Avanzada (ORFEO-CINQA), Universidad de Zaragoza - CSIC, 50009 Zaragoza, Spain \\ Supporting Information Placeholder
}

\begin{abstract}
The preparation of new osmium-hydride complexes, starting from $\mathrm{OsH}_{6}\left(\mathrm{P}^{\mathrm{i}} \mathrm{Pr}_{3}\right)_{2}(\mathbf{1})$ and $\mathrm{OsH}_{2} \mathrm{Cl}_{2}\left(\mathrm{P}^{\mathrm{i}} \mathrm{Pr}_{3}\right)_{2}(\mathbf{2})$, and their catalytic activity in acceptorless dehydrogenative coupling of alcohols and amines and in dehydrogenation of cyclic amines are reported. Complex 1 reacts with acetylacetone (Hacac) to give the classical trihydride $\mathrm{OsH}_{3}(\mathrm{acac})\left(\mathrm{P}^{\mathrm{i}} \mathrm{Pr}_{3}\right)_{2}(3)$. The protonation of 3 with triflic acid (HOTf) produces the release of $\mathrm{H}_{2}$ and the formation of the unsaturated osmium(IV)-dihydride $\left[\mathrm{OsH}_{2}(\mathrm{acac})\left(\mathrm{P}^{\mathrm{i}} \mathrm{Pr}_{3}\right)_{2}\right] \mathrm{OTf}(\mathbf{4})$, which is also prepared starting from 2 via the intermediate $\mathrm{OsH}_{2} \mathrm{Cl}(\mathrm{acac})\left(\mathrm{P}^{\mathrm{i}} \mathrm{Pr}_{3}\right)_{2}$ (5). Treatment of acetylacetone solutions of 5 with $\mathrm{KOH}$ affords $\mathrm{Os}(\mathrm{acac})_{2}\left(\mathrm{P}^{\mathrm{i}} \mathrm{Pr}_{3}\right)_{2}(\mathbf{6})$. In presence of $5 \mathrm{~mol} \%$ of $\mathrm{KOH}$, complexes 3-6 promote the coupling of benzylalcohol and aniline to give $N$-benzylideneaniline and $\mathrm{H}_{2}$. Under the same conditions, complex 3 catalyzes a wide range of analogous couplings to afford a variety of imines, including aliphatic ones, with yields between 90 and $40 \%$ after $1-48 \mathrm{~h}$. Complex 3 also catalyzes the dehydrogenation of cyclic amines. According to the amount of $\mathrm{H}_{2}$ released by each gram of employed substrate, the amines have been classified into three classes: poor- (1,2,3,4-tetrahydroquinaldine, 2-methylindoline and 2,6dimethylpiperidine), moderate- (1,2,3,4-tetrahydroquinoline and 6-methyl-1,2,3,4-tetrahydroquinoline) and good-hydrogen donors (1,2,3,4-tetrahydroisoquinoline).
\end{abstract}

\section{INTRODUCTION}

One of the goals of the chemist of this century is to make the chemical synthesis environmentally friendly. In this respect, the improvement of the efficiency of atom-economical methodologies is challenging. ${ }^{1}$ Among the processes of this class, those yielding useful byproducts from an energy point of view are of special interest, in particular acceptorless dehydrogenation reactions and related transformations, ${ }^{2}$ which afford molecular hydrogen, the most efficient and clean energy carrier known. ${ }^{3}$

Imines, which are intermediates in the synthesis of several biologically active $N$-heterocyclic compounds, show a rich reactivity. ${ }^{4}$ As a consequence, they have widespread applications in the laboratory and in the industry. ${ }^{5}$ Traditional methods for their synthesis, relatively benign from an environmental point of view, are the condensation of a carbonyl compound with an amine, ${ }^{6}$ the aerobic metal-catalyzed selfcondensation of amines, ${ }^{7}$ the aerobic metal-mediated coupling of alcohols and amines, ${ }^{8}$ and the hydroamination of alkynes. In 2010, Milstein and co-workers reported that PNN-pincer ruthenium complexes can promote the synthesis of imines, with liberation of molecular hydrogen, by means of the coupling of alcohols and amines under argon. ${ }^{10} \mathrm{We}$ a year later proved that the osmium-tetrahydride $\mathrm{OsH}_{4}\left\{\kappa^{3}\right.$-POP$\left.\left[\mathrm{dbf}\left(\mathrm{P}^{\mathrm{i}} \mathrm{Pr}_{2}\right)_{2}\right]\right\} \quad\left(\mathrm{dbf}\left(\mathrm{P}^{\mathrm{i}} \mathrm{Pr}_{2}\right)_{2} \quad=\quad 4,6-\right.$ bis(diisopropylphosphino)dibenzofuran) is a promising alternative to the ruthenium catalysts. ${ }^{11}$ The reaction has awaken a great interest ${ }^{12}$ and catalysts of other metals including manga- nese, ${ }^{13}$ iron, ${ }^{14}$ cobalt, ${ }^{15}$ and iridium ${ }^{16}$ have been also reported. Recently, ruthenium-catalyzed coupling of nitriles with alcohols to give imines has been independently reported by Nikonov $^{17}$ and Hong ${ }^{18}$.

One of the barriers to adopting the hydrogen technology is the lack of an adequate method for its storage. ${ }^{19}$ In this context, organic liquids are a promising alternative, since they can be reversibly dehydrogenated. ${ }^{20}$ Initial efforts to develop this class of carriers were focused on cycloalkanes. However, their large enthalpy of dehydrogenation is a drawback for practical applications. The introduction of a heteroatom into the ring system significantly decreases the enthalpy of dehydrogenation. $^{21}$ This has led to some groups to explore the metalpromoted dehydrogenation of cyclic amines. As a consequence, iron, ${ }^{22}$ ruthenium, ${ }^{23}$ cobalt, ${ }^{24}$ iridium,${ }^{25}$ nickel, ${ }^{26}$ palladium, ${ }^{27}$ and copper $^{28}$ catalysts have been developed in order to perform this reaction under acceptorless conditions.

The ability of polyhydrides of platinum group metals to activate $\sigma$-bonds allows them to be starting compounds for preparing new complexes and to interact with several fields, including the organic synthetic chemistry and the storage of regenerative energy. ${ }^{29}$ Thus several ruthenium-, ${ }^{30}$ rhodium-, ${ }^{31}$ and iridium-polyhydride ${ }^{32}$ complexes take part in a wide range of metal-promoted organic synthetic processes and in the kinetically controlled dehydrocoupling of amineboranes. ${ }^{33}$ In contrast to ruthenium, rhodium, and iridium, osmiumpolyhydrides have received scarce attention and only a few compounds of this class have proved to be useful in catalysis. In opposition to $\mathrm{OsH}_{4}\left\{\kappa^{3}-\mathrm{POP}-\left[\mathrm{dbf}\left(\mathrm{P}^{\mathrm{i}} \mathrm{Pr}_{2}\right)_{2}\right]\right\}$, the PNP-pincer 
tetrahydride $\mathrm{OsH}_{4}\left\{\kappa^{3}-\mathrm{PNP}-\left[\mathrm{NH}\left(\mathrm{CH}_{2} \mathrm{CH}_{2} \mathrm{P}^{\mathrm{i}} \mathrm{Pr}_{2}\right)_{2}\right]\right\} \quad$ couples primary alcohols and primary amines to afford secondary amines; it also promotes the dehydrogenative coupling of primary alcohols to symmetrical esters and the hydrogen transfer from 2-propanol to ketones. ${ }^{34}$ The cis-hydride-dihydrogen $\left[\mathrm{OsH}\left(\eta^{2}-\mathrm{H}_{2}\right)\left\{\kappa^{4}-\mathrm{P}, \mathrm{P}, \mathrm{P}, \mathrm{P}-\left[\mathrm{P}\left(\mathrm{CH}_{2} \mathrm{CH}_{2} \mathrm{PPh}_{2}\right)_{2}\right]\right\}\right] \mathrm{BPh}_{4}$ catalyzes the hydrogen transfer from 2-propanol to $\alpha, \beta$-unsaturated ketones to yield saturated ketones via isomerization of the initially produced allylic alcohol. ${ }^{35}$ Saturated ketones by direct reduction of the $\mathrm{C}-\mathrm{C}$ double bond of $\alpha, \beta$-unsaturated ketones with molecular hydrogen are formed in the presence of the carbonyl-hydride-dihydrogen catalysts $\mathrm{OsHCl}\left(\eta^{2}\right.$ $\left.\mathrm{H}_{2}\right)(\mathrm{CO})\left(\mathrm{PR}_{3}\right)_{2} \quad\left(\mathrm{PR}_{3}=\mathrm{P}^{\mathrm{i}} \mathrm{Pr}_{3}, \mathrm{P}^{\mathrm{t}} \mathrm{Bu}_{2} \mathrm{Me}\right){ }^{36}$ The equilibrium mixture of the dihydride $\mathrm{OsH}_{2}(\mathrm{CO})\left(\mathrm{P}^{\mathrm{i}} \mathrm{Pr}_{3}\right)_{2}$ and the dihydridedihydrogen $\mathrm{OsH}_{2}\left(\eta^{2}-\mathrm{H}_{2}\right)(\mathrm{CO})\left(\mathrm{P}^{\mathrm{i}} \mathrm{Pr}_{3}\right)_{2}$ catalyzes the dehydrogenation of ammoniaborane; ${ }^{37}$ the hydrogen transfer from 2propanol to ketones, $\alpha, \beta$-unsaturated ketones, ${ }^{38}$ and terminal alkynes $;{ }^{39}$ and the dimerization of terminal alkynes to butatrienes. ${ }^{40}$ In contrast to the triisopropylphosphine system, the POP-xanthene tetrahydride $\mathrm{OsH}_{4}\left\{\kappa^{3}-\mathrm{POP}-\left[\mathrm{xant}\left(\mathrm{P}^{\mathrm{i}} \mathrm{Pr}_{2}\right)_{2}\right]\right\}$ $\left(x a n t\left(\mathrm{P}^{\mathrm{i}} \mathrm{Pr}_{2}\right)_{2} \quad=\quad\right.$ 9,9-dimethyl-4,5bis(diisopropylphosphino)xanthene) affords enynes. ${ }^{41}$

In the search for new useful osmium-polyhydrides in catalysis we have explored the reactions of $\mathrm{OsH}_{6}\left(\mathrm{P}^{\mathrm{i}} \mathrm{Pr}_{3}\right)_{2}(\mathbf{1})$ and $\mathrm{OsH}_{2} \mathrm{Cl}_{2}\left(\mathrm{P}^{\mathrm{i}} \mathrm{Pr}_{3}\right)_{2}$ (2) with acetylacetone (Hacac). In this paper we report the preparation of new osmium-polyhydrides containing the acetylacetonate (acac) ligand and their ability to promote both types of reactions: the coupling of alcohols and amines to selectively yield imines with hydrogen release and the dehydrogenation of cyclic amines.

\section{RESULTS AND DISCUSSION}

Preparation and characterization of the catalyst precursors. The hydride ligands of the $d^{2}$-hexahydride complex $\mathbf{1}$ have proved to be basic enough to promote the deprotonation of polar $\mathrm{C}-\mathrm{H},{ }^{42} \mathrm{~N}-\mathrm{H},{ }^{43}$ and $\mathrm{O}-\mathrm{H}^{44} \sigma$-bonds. In agreement with this, treatment of toluene solutions of 1 with 2 equiv of Hacac, under reflux, for $1 \mathrm{~h}$ leads to the trihydride derivative $\mathrm{OsH}_{3}(\mathrm{acac})\left(\mathrm{P}^{\mathrm{i}} \mathrm{Pr}_{3}\right)_{2}$ (3) and $\mathrm{H}_{2}$ (Scheme 1).

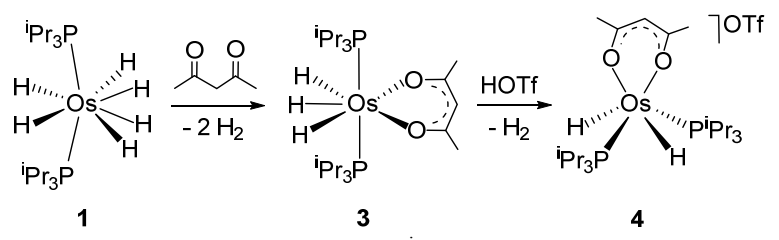

Scheme 1. Reaction of $\mathrm{OsH}_{6}\left(\mathrm{P}^{\mathrm{i}} \mathrm{Pr}_{3}\right)_{2}$ with Acetylacetone.

Complex 3 was isolated as a yellow solid in $83 \%$ yield and characterized by X-ray diffraction analysis. Figure 1 shows a view of the molecule. The coordination geometry around the osmium atom can be described as a distorted pentagonal bipyramid with axial phosphines $\left(\mathrm{P}(1)-\mathrm{Os}-\mathrm{P}(2)=172.557(19)^{\circ}\right)$. The metal coordination sphere is completed by the hydride ligands, separated by $1.59(3) \AA(\mathrm{H}(01)-\mathrm{H}(02))$ and $1.58(3) \AA$ $(\mathrm{H}(02)-\mathrm{H}(03))$, and the oxygen atoms of the acac group, which acts with an $\mathrm{O}(1)-\mathrm{Os}-\mathrm{O}(2)$ bite angle of $83.17(6)^{\circ}$. The classical trihydride nature of the complex was confirmed by the DFT-optimized structure (B3LYP(GD3)//SDD/6-31G**) and the hydride resonances in the ${ }^{1} \mathrm{H}$ NMR spectrum. The DFT calculations yield separations between the hydrides of 1.590 and $1.603 \AA$, which agree well with that obtained from the $\mathrm{X}$ ray diffraction analysis. The ${ }^{1} \mathrm{H}$ NMR spectrum, in toluene- $d_{8}$, is temperature-dependent. At room temperature, it displays a triplet $\left({ }^{2} J_{\mathrm{H}-\mathrm{P}}=12.2 \mathrm{~Hz}\right)$ at $-12.83 \mathrm{ppm}$ for the hydride ligands, indicating that the central hydride is involved in a thermally activated intramolecular exchange process $\left(\Delta G^{*}=12 \mathrm{kcal}\right.$ $\mathrm{mol}^{-1}$ ) with the hydrides of the corners. Thus, between $243 \mathrm{~K}$ and $233 \mathrm{~K}$, decoalescence occurs and at temperatures lower than $223 \mathrm{~K}$ an $\mathrm{A}_{2} \mathrm{BX}_{2}\left(\mathrm{X}={ }^{31} \mathrm{P}\right)$ spin system is observed with $\delta_{\mathrm{A}}=-12.51, \delta_{\mathrm{B}}=-13.14$ and $J_{\mathrm{AB}}=17 \mathrm{~Hz}$. For these resonances $300 \mathrm{MHz} T_{1}(\mathrm{~min})$ values of $83 \pm 3 \mathrm{~ms}\left(\delta_{\mathrm{A}}\right)$ and $53 \pm 3 \mathrm{~ms}\left(\delta_{\mathrm{B}}\right)$ were obtained at $213 \mathrm{~K}$, which fit with a hydrogen-hydrogen separation of $1.63 \AA .{ }^{45}$ In contrast to the ${ }^{1} \mathrm{H}$ NMR spectrum, the ${ }^{31} \mathrm{P}\left\{{ }^{1} \mathrm{H}\right\}$ NMR spectrum is temperature invariant. Between $283 \mathrm{~K}$ and $183 \mathrm{~K}$, it shows a singlet at $36.6 \mathrm{ppm}$.

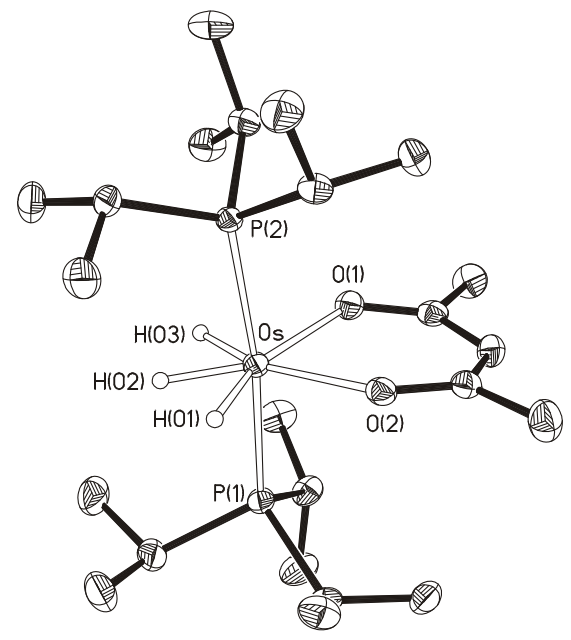

Figure 1. ORTEP diagram of complex 3 (50\% probability ellipsoids). Hydrogen atoms (except the hydrides) are omitted for clarity. Selected bond lengths $(\AA)$ and angles (deg): Os-P $(1)=$ $2.3402(6)$, Os- $\mathrm{P}(2)=2.3386(6)$, Os-O $(1)=2.1560(16)$, Os-O $(2)=$ $2.1612(16), \mathrm{H}(01)-\mathrm{H}(02)=1.59(3), \mathrm{H}(02)-\mathrm{H}(03)=1.58(3) ; \mathrm{P}(1)-$ Os-P(2) = 172.557(19), O(1)-Os-O(2) = 83.17(6).

Complex 3 is also a Brønsted base. At least one of the hydride ligands is responsible for this character. Thus, the addition of 1.0 equiv of triflic acid (HOTf) to dichloromethane solutions of 3 produces the release of $\mathrm{H}_{2}$, as a result of the protonation of the basic hydride, and the formation of the sixcoordinate dihydride $\left[\mathrm{OsH}_{2}(\mathrm{acac})\left(\mathrm{P}^{\mathrm{i}} \mathrm{Pr}_{3}\right)_{2}\right] \mathrm{OTf}(4)$, which was isolated as a pale yellow solid in $87 \%$ yield. The saline character of this compound is strongly supported by its molar conductivity of $134 \mathrm{ohm}^{-1} \mathrm{~cm}^{2} \mathrm{~mol}^{-1}$, at $25^{\circ} \mathrm{C}$, in acetone. The ${ }^{1} \mathrm{H}$ NMR spectrum, in dichloromethane- $d_{2}$, at room temperature is the expected one for a 16-valence electron osmium(IV) $\mathrm{OsH}_{2} \mathrm{X}_{2}\left(\mathrm{P}^{\mathrm{i}} \mathrm{Pr}_{3}\right)_{2}$ species with a structure in the solid state that can be described as a $\mathrm{C}_{2}$-square antiprism with two missing vertexes. ${ }^{43 c, 46}$ Thus, it contains at $1.28 \mathrm{ppm}$ the characteristic double doublet $\left({ }^{3} J_{\mathrm{H}-\mathrm{H}}=7.2 \mathrm{~Hz},{ }^{2} J_{\mathrm{H}-\mathrm{P}}=14.5 \mathrm{~Hz}\right)$ due to the $\mathrm{P}^{\mathrm{i}} \mathrm{Pr}_{3}$ methyl groups, whereas the $\mathrm{OsH}_{2}$ unit gives rise to a triplet $\left({ }^{2} J_{\mathrm{H}-\mathrm{P}}=34.7 \mathrm{~Hz}\right)$ at $-19.67 \mathrm{ppm}$. The ${ }^{31} \mathrm{P}\left\{{ }^{1} \mathrm{H}\right\} \mathrm{NMR}$ spectrum shows a singlet at $37.1 \mathrm{ppm}$.

Complex 4 can be also prepared starting from 2, by means of the reactions sequence summarized in Scheme 2. Treatment of acetylacetonate solutions of 2 with 1.0 equiv of $\mathrm{KOH}$, at room temperature, for $5 \mathrm{~h}$ produces the substitution of one of the chloride ligands by an acac group and the formation of the seven-coordinate derivative $\mathrm{OsH}_{2} \mathrm{Cl}(\mathrm{acac})\left(\mathrm{P}^{\mathrm{i}} \mathrm{Pr}_{3}\right)_{2}$ (5), which 
was isolated as a yellow solid in $64 \%$ yield. Addition of 1.0 equiv of AgOTf dissolved in some drops of acetone to dichloromethane solutions of 5 gives rise to the extraction of the chloride anion to yield 4 in $68 \%$ yield. The ${ }^{1} \mathrm{H}$ and ${ }^{31} \mathrm{P}\left\{{ }^{1} \mathrm{H}\right\}$ NMR spectra of 5 , in benzene- $d_{6}$, at room temperature resembles those of complexes $\mathrm{OsH}_{2}\left(\kappa^{2}-\mathrm{O}_{2} \mathrm{CCH}_{3}\right) \mathrm{X}\left(\mathrm{P}^{\mathrm{i}} \mathrm{Pr}_{3}\right)_{2}(\mathrm{X}=\mathrm{Cl}$, $\left.\mathrm{OC}(\mathrm{O}) \mathrm{CH}_{3}\right) .{ }^{47}$ Thus, the ${ }^{1} \mathrm{H}$ NMR spectrum displays a double doublet $\left({ }^{3} J_{\mathrm{H}-\mathrm{H}}=7.2 \mathrm{~Hz},{ }^{2} J_{\mathrm{H}-\mathrm{P}}=12.4 \mathrm{~Hz}\right)$ at $1.24 \mathrm{ppm}$ for the $\mathrm{P}^{\mathrm{i}} \mathrm{Pr}_{3}$ methyl groups, whereas the hydride ligands give rise to a triplet $\left({ }^{2} J_{\mathrm{H}-\mathrm{P}}=35.5 \mathrm{~Hz}\right)$ at $-12.77 \mathrm{ppm}$. The ${ }^{31} \mathrm{P}\left\{{ }^{1} \mathrm{H}\right\}$ NMR spectrum shows a singlet at $24.1 \mathrm{ppm}$. On the basis of an $\mathrm{X}$ ray diffraction analysis of $\mathrm{OsH}_{2}\left(\kappa^{2}-\mathrm{O}_{2} \mathrm{CCH}_{3}\right)\left\{\kappa^{1}-\right.$ $\left.\mathrm{OC}(\mathrm{O}) \mathrm{CH}_{3}\right\}\left(\mathrm{P}^{\mathrm{i}} \mathrm{Pr}_{3}\right)_{2}$, the coordination polyhedron around the osmium atom of these compounds has been described as a halfway situation between a capped trigonal prism and a piano stool geometry. If one takes as a base the structure of $\mathbf{2 , 4}, \mathbf{4}$, and related six-coordinate osmium(IV)-dihydrides, ${ }^{46}$ the coordination polyhedron could be rationalized as a square antiprism with a missing vertex.

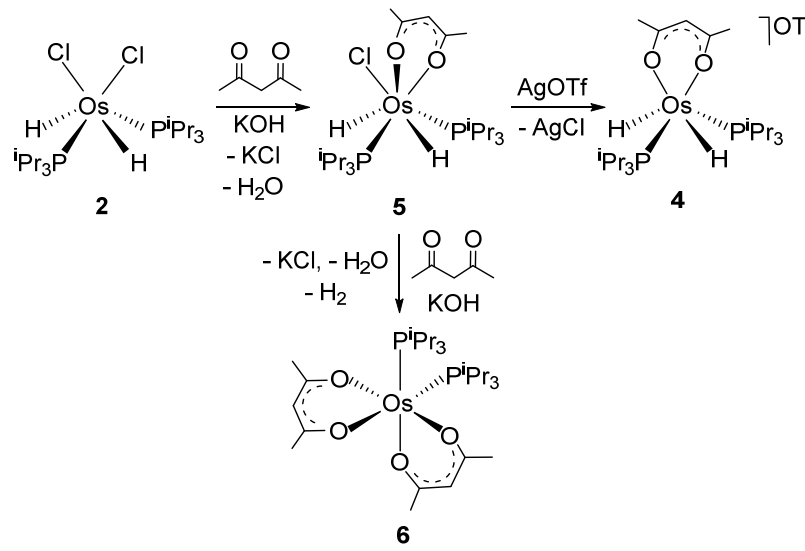

Scheme 2. Reaction of $\mathrm{OsH}_{2} \mathrm{Cl}_{2}\left(\mathrm{P}^{\mathrm{i}} \mathrm{Pr}_{3}\right)_{2}$ with Acetylacetone

Complex 5 has a higher trend than 2 to release $\mathrm{H}_{2}$. In contrast to the latter, the treatment of acetylacetone solutions of the former with 1.0 equiv of $\mathrm{KOH}$ produces the reductive elimination of $\mathrm{H}_{2}$ and the formation of the six-coordinate osmium(II) derivative cis-Os(acac $)_{2}\left(\mathrm{P}^{\mathrm{i}} \mathrm{Pr}_{3}\right)_{2}$ (6), which was isolated as a red solid in low yield $(\approx 20 \%)$ and characterized by X-ray diffraction analysis. Figure 2 shows a view of the molecule. The geometry around the osmium atom can be rationalized as a very distorted octahedron with cis phosphine ligands. The distortion is mainly due to the arrangement of the phosphine ligands, which experience a large steric hindrance due to their large cone angle $\left(160^{\circ}\right) .^{48}$ As a consequence, the P-Os-P angle $\left(104.85(2)^{\circ}\right)$ strongly deviates from the ideal value of $90^{\circ}$. 49 The ${ }^{31} \mathrm{P}\left\{{ }^{1} \mathrm{H}\right\}$ NMR spectrum, in benzene- $d_{6}$, at room temperature shows a singlet at $-12.2 \mathrm{ppm}$, as expected for equivalent phosphines.

We note that the related complex cis-Ru(acac $)_{2}\left(\mathrm{P}^{\mathrm{i}} \mathrm{Pr}_{3}\right)_{2}$ has been previously reported by the groups of Werner and Bennett and characterized by X-ray diffraction analysis. ${ }^{50}$ It was prepared by displacement of the $\mathrm{L}$ ligands of $\mathrm{Ru}(\mathrm{acac})_{2} \mathrm{~L}_{2}(\mathrm{~L}=$ $\mathrm{Sb}^{\mathrm{i}} \mathrm{Pr}_{3}, \mathrm{C}_{8} \mathrm{H}_{14}$ ) by $\mathrm{P}^{\mathrm{i}} \mathrm{Pr}_{3}$, in benzene or tetrahydrofuran, at room temperature. When the reaction was performed at $-25^{\circ} \mathrm{C}$, in tetrahydrofuran, the trans isomer was isolated. The latter rapidly isomerizes to $c i s-\mathrm{Ru}(\mathrm{acac})_{2}\left(\mathrm{P}^{\mathrm{i}} \mathrm{Pr}_{3}\right)_{2}$ at room temperature.

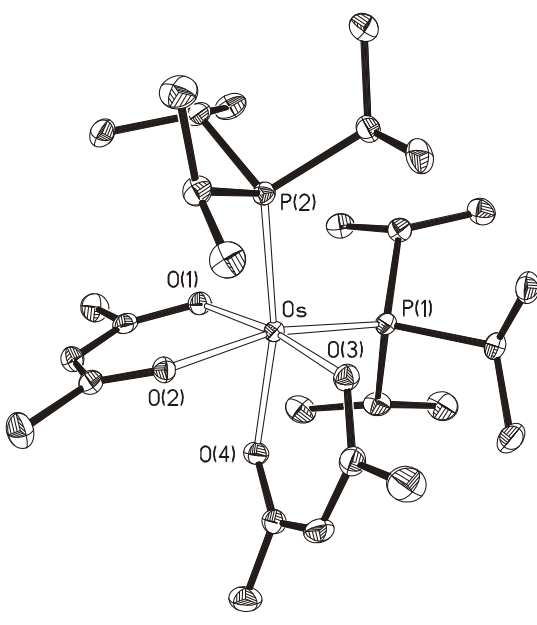

Figure 2. ORTEP diagram of complex 6 (50\% probability ellipsoids). Hydrogen atoms are omitted for clarity. Selected bond lengths $(\AA)$ and angles $(\mathrm{deg})$ : Os- $\mathrm{P}(1)=2.3174(6)$, Os- $\mathrm{P}(2)=$ $2.3213(6)$, Os-O(1) = 2.0669(16), Os-O (2) = 2.1038(16), Os-O(3) $=2.0706(16)$, Os-O(4) = 2.0940(16); $\mathrm{P}(1)-\mathrm{Os}-\mathrm{P}(2)=104.85(2)$, $\mathrm{O}(1)-\mathrm{Os}-\mathrm{O}(2)=90.54(6), \mathrm{O}(3)-\mathrm{Os}-\mathrm{O}(4)=90.50(7)$.

Catalytic formation of imines with release of molecular hydrogen. In the presence of $\mathrm{KOH}$, complexes 3-6 are efficient catalyst precursors for the coupling of benzyl alcohol and aniline, under argon, which yields $N$-benzylideneaniline with liberation of molecular hydrogen and water. The coupling was performed in toluene under reflux, using alcohol and amine concentrations of $1.63 \mathrm{M}$ and precursor/substrates and $\mathrm{KOH} /$ substrates molar ratios of $1 / 100$ and $1 / 20$, respectively. The water generated during the process was removed from the reaction medium by using a Dean-Stark receiver filled with toluene. Under these conditions, the trihydride complex $\mathbf{3}$ is the most active precursor (Table 1), since it promotes the formation of the imine in $82 \%$ yield, after $1 \mathrm{~h}$ of reaction, while complexes $4-6$ reach $73-66 \%$ of product. Furthermore, between $14 \%$ and $24 \%$ of $N$-phenylbenzylamine is obtained as a consequence of the reduction of $N$-benzylideneaniline. The lowest amine/imine ratio is also observed when the dihydride 3 is used. So, this complex is the most active and the most selective precursor.

Table 1. Screening of Catalysts for the Formation of $\mathrm{N}$ Benzylideneaniline with Release of Molecular Hydrogen ${ }^{\text {a }}$

\begin{tabular}{cccc}
\hline complex & yield $(\%)^{\mathrm{b}}$ & yield $(\%)^{\mathrm{b}}$ & 0.17 \\
4 & 82 & 21 & 0.29 \\
5 & 73 & 14 & 0.21 \\
6 & 66 & 24 & 0.34 \\
\hline
\end{tabular}

Catalyst $(0.0163 \mathrm{mmol})$, benzylic alcohol $(1.63 \mathrm{mmol})$, aniline $(1.63 \mathrm{mmol}), \mathrm{KOH}(0.081 \mathrm{mmol})$, and toluene $(1 \mathrm{~mL})$ were heated at $110{ }^{\circ} \mathrm{C}$ in a Schlenk tube under an argon atmosphere for $1 \mathrm{~h} .{ }^{b}$ Yields were determined by ${ }^{1} \mathrm{H}$ NMR spectroscopy. 
Table 2. Synthesis of Imines from Alcohols and Amines Catalyzed by $\mathrm{OsH}_{3}(\operatorname{acac})\left(\mathrm{P}^{\mathrm{i}} \mathrm{Pr}_{3}\right)_{2}{ }^{\mathrm{a}}$

\begin{tabular}{|c|c|c|c|c|}
\hline run & RR'CHOH & $\mathrm{R}{ }^{\prime} \mathrm{NH}_{2}$ & t (h) & $\begin{array}{l}\text { NMR yield } \\
(\%)^{\mathbf{b}}\end{array}$ \\
\hline 1 & & & 1 & $\begin{array}{l}82 \text { imine, } \\
14 \text { amine }\end{array}$ \\
\hline 2 & & & 24 & $\begin{array}{l}73 \text { imine, } \\
27 \text { amine }\end{array}$ \\
\hline 3 & $\mathrm{OH}$ & & 24 & 26 imine \\
\hline 4 & & & 24 & $\begin{array}{l}48 \text { imine, } \\
1 \text { amine }\end{array}$ \\
\hline 5 & & & 3 & $\begin{array}{l}80 \text { imine, } \\
8 \text { amine }\end{array}$ \\
\hline 6 & & & 12 & $\begin{array}{l}94 \text { imine, } \\
2 \text { amine }\end{array}$ \\
\hline 7 & & & 12 & 83 imine, \\
\hline 8 & & & 8 & $\begin{array}{l}92 \text { imine, } \\
1 \text { amine }\end{array}$ \\
\hline 9 & $\mathrm{OH}$ & & 12 & 70 imine, \\
\hline 10 & & & 12 & $\begin{array}{l}56 \text { imine, } \\
35 \text { amine }\end{array}$ \\
\hline 11 & & & 48 & 33 imine \\
\hline 12 & $\mathrm{OH}$ & & 24 & 90 imine \\
\hline 13 & $\mathrm{OH}$ & & 24 & 10 imine \\
\hline 14 & & & 24 & $\begin{array}{l}40 \text { imine, } \\
6 \text { amine }\end{array}$ \\
\hline 15 & & & 48 & $\begin{array}{l}68 \text { imine, } \\
5 \text { amine }\end{array}$ \\
\hline
\end{tabular}

${ }^{\mathrm{a}}$ Complex 3 (0.0163 mmol), alcohol (1.63 mmol), amine (1.63 mmol), KOH (0.081 mmol), and toluene $(1 \mathrm{~mL})$ were heated at $110^{\circ} \mathrm{C}$ in a Schlenk tube under an argon atmosphere.

${ }^{\mathrm{b}}$ Yields were determined by ${ }^{1} \mathrm{H}$ NMR spectroscopy. 
Complex 3 promotes the formation of a variety of imines, including aliphatic ones that are inherently more challenging due to their instability. Yields of imine between $90 \%$ and $40 \%$ are obtained after 1-48 $\mathrm{h}$ depending upon the nature of both alcohol and amine (Table 2). In addition to the reduced product, aldehyde (1-2\%) or ketone (16-23\%) is also observed during the reactions. Its presence is consistent with a two-step procedure for the formation of the imines, which involves the catalytic dehydrogenation of the alcohol, to afford the aldehyde or ketone and molecular hydrogen, and the subsequent condensation of the amine with the generated carbonyl intermediate (Scheme 3). In contrast, the carbonyl intermediate was not detected during the ruthenium-mediated amide synthesis by coupling of alcohol and amines.

$$
\begin{aligned}
& \mathrm{RR}^{\prime} \mathrm{CHOH} \stackrel{[\mathrm{Os}]}{\longrightarrow} \stackrel{\mathrm{O}}{\longrightarrow} \mathrm{RCR}^{\prime}+\mathrm{H}_{2} \\
& \mathrm{RCR}^{\mathrm{O}}+\mathrm{R}^{\prime \prime} \mathrm{NH}_{2} \longrightarrow \mathrm{R}-\mathrm{-}_{\mathrm{N}-\mathrm{R} \mathrm{R}^{\prime \prime}}^{\mathrm{R}}+\mathrm{H}_{2} \mathrm{O} \\
& \mathrm{RR}{ }^{\prime} \mathrm{CHOH}+\mathrm{R}^{\prime \prime} \mathrm{NH}_{2} \stackrel{[\mathrm{Os}]}{\longrightarrow} \mathrm{R}_{\mathrm{N}-\mathrm{R}^{\prime \prime}}^{\mathrm{R}^{\prime}}+\mathrm{H}_{2} \mathrm{O}+\mathrm{H}_{2}
\end{aligned}
$$

Scheme 3. Two-step Procedure for the Formation of Imines.

A chloride substituent at para position of benzyl alcohol decreases the rate of formation of the imine. While benzyl alcohol affords $82 \%$ of $N$-benzylideneaniline after 1 hour (run 1), $p$-chlorobenzyl alcohol needs $24 \mathrm{~h}$ to give $73 \%$ of $N$-(4chlorobenzylidene)aniline (run 2). The primary or secondary nature of the alcohol has a marked influence on the rate and selectivity of the reactions. In contrast to benzyl alcohol, 1phenylethanol (run 3) and diphenylmethanol (run 4) afford significant amounts of the carbonyl intermediate $(16 \%$ and $23 \%$, respectively), whereas the yields of the respective imines, 26 and 48\%, are moderate. Benzyl alcohol couples with methyl substituted anilines and aliphatic amines, including benzylamine, cyclohexylamine and dodecylamine. The methyl substituent of anilines has a marked influence on the reaction (runs 1, 5 and 6 ). Its presence decreases the rate. The effect enhances as the methyl group approaches to the nitrogen atom. While $N$-benzylidene- $p$-methylaniline is obtained in $80 \%$ yield after $3 \mathrm{~h}$, the formation of similar amount of $N$ benzylidene-o-methylaniline requires about $12 \mathrm{~h}$. The presence of the methyl group at the anilines has also some influence on the selectivity of the reaction, decreasing the formation of reduced product in the sequence aniline $>p$ methylaniline $>o$-methylaniline. Aliphatic amines also work well; benzylamine (run 7), cyclohexylamine (run 8) and dodecylamine (run 9) lead to the corresponding imines in 92$70 \%$ yield after $8-12 \mathrm{~h}$. The selectivity of the reactions increases as the bulkiness of the alkyl group also increases. Thus, the formation of the reduced product decreases in the sequence dodecylamine $>$ benzylamine $>$ cyclohexylamine. Cyclohexylmethanol (runs 10-12) and $n$-butanol (runs 13-15) react more slowly than benzyl alcohol. Thus, long times, 24$48 \mathrm{~h}$, are necessary to obtain the corresponding imines in moderate-high yields. In contrast to benzyl alcohol, with these alcohols, the reactions involving aliphatic amines, in particular dodecylamine (runs 12 and 15), are faster than those with anilines.

The results collected in Table 2 reaffirm that osmium is certainly a real alternative to ruthenium for the synthesis of imines from alcohols and amines with liberation of molecular hydrogen. The POP tetrahydride complex $\mathrm{OsH}_{4}\left\{\kappa^{3}-\mathrm{POP}-\right.$ $\left.\left[\mathrm{dbf}\left(\mathrm{P}^{1} \mathrm{Pr}_{2}\right)_{2}\right]\right\}^{11}$ has shown to be significantly more efficient than the reported ruthenium systems. ${ }^{12}$ The efficiency of $\mathbf{3}$ as catalyst precursor for this reaction is slightly lower than that of $\mathrm{OsH}_{4}\left\{\kappa^{3}-\mathrm{POP}-\left[\mathrm{dbf}\left(\mathrm{P}^{\mathrm{i}} \mathrm{Pr}_{2}\right)_{2}\right]\right\}$ in terms of activity and selectivity. However, the simplicity of the ligands of 3 , which are further commercially available, and the speed and high yield of the procedure discovered for its preparation are enough facts to compensate the lower efficiency and do the use of this precursor a recommendable alternative.

Catalytic dehydrogenation of cyclic amines. Complex 3 also promotes the dehydrogenation of cyclic amines, such as 1,2,3,4-tetrahydroquinoline, 1,2,3,4-tetrahydroquinaldine, 6methyl-1,2,3,4-tetrahydroquinoline, 1,2,3,4tetrahydroisoquinoline, 2-methylindoline, and 2,6dimethylpiperidine, to the corresponding aromatic compounds (eq 1). The reactions were performed under argon, in $p$-xylene, at $140{ }^{\circ} \mathrm{C}$, using an heterocycle concentration of $0.16 \mathrm{M}$ and a precursor/substrate molar ratio of $1 / 10$. Under these conditions, the aromatic heterocycles were formed with yields between $100 \%$ and $29 \%$, after $48 \mathrm{~h}$, depending upon the position of the nitrogen atom at the heterocycle and the presence of methyl substituents adjacent to the heteroatom (Table 3 ). The trend of the cyclic amine to undergo dehydrogenation increases as the space around the nitrogen atom also increases, i.e., in the sequence 1,2,3,4-tetrahydroquinaldine $<1,2,3,4-$ tetrahydroquinoline $<1,2,3,4$-tetrahydroisoquinoline (runs $2<$ $1<4$ ). This suggests that the coordination of the nitrogen atom to the metal center of the catalyst is the key step for the dehydrogenation.

[Os]

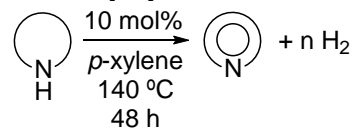

The studied amines can be classified into three classes, according to the amount of molecular hydrogen released by each gram of used heterocycle: poor-, moderate- and goodhydrogen donors. 1,2,3,4-Tetrahydroquinaldine (run 2), 2methylindoline (run 5), and 2,6-dimethylpiperidine (run 6) are poor-hydrogen donors. A structural characteristic of these substrates is the presence of two carbons bonded to the carbons adjacent to the heteroatom. They release between 0.59 . $10^{-2}$ and $0.77 \cdot 10^{-2} \mathrm{~mol} \mathrm{~g}^{-1} .1,2,3,4$-Tetrahydroquinoline (run 1) and 6-methyl-1,2,3,4-tetrahydroquinoline (run 3) are moderate-hydrogen donors. In contrast to the poor-hydrogen donor heterocycles, in these substrates only one of the adjacent carbons to the heteroatom has two bonded carbons. They afford about $1.2 \cdot 10^{-2} \mathrm{~mol} \mathrm{~g}^{-1}$. 1,2,3,4-Tetrahydroisoquinoline (run 4), with both carbons adjacent to the heteroatom bonded to one carbon, is a good-hydrogen donor. After $48 \mathrm{~h}$, it releases all its capacity, $1.50 \cdot 10^{-2} \mathrm{~mol} \mathrm{~g}^{-1}$. 
Table 3. Osmium Catalyzed Acceptorless Dehydrogenation of Cyclic Amines ${ }^{\mathrm{a}}$

\begin{tabular}{|c|c|c|c|c|}
\hline run & substrate & product & $\begin{array}{l}\text { yield } \\
(\%)^{b}\end{array}$ & $\begin{array}{l}\mathbf{m o l ~ H}_{2} / \mathbf{g} \\
\text { substrate }\end{array}$ \\
\hline 1 & & & 80 & $1.20 \cdot 10^{-2}$ \\
\hline 2 & & & 44 & $0.59 \cdot 10^{-2}$ \\
\hline 3 & & & 82 & $1.11 \cdot 10^{-2}$ \\
\hline 4 & & & 100 & $1.50 \cdot 10^{-2}$ \\
\hline 5 & & & 100 & $0.75 \cdot 10^{-2}$ \\
\hline 6 & & & 29 & $0.77 \cdot 10^{-2}$ \\
\hline
\end{tabular}

Conditions: 3 (0.0163 mmol); $N$-heterocyclic substrate $(0.163 \mathrm{mmol})$; $p$-xylene $(1 \mathrm{~mL})$ heated at $140{ }^{\circ} \mathrm{C}$ for $48 \mathrm{~h}$. Conversions were calculated from the relative peak area integrations of the reactant and product in the GC spectra.

Complex $\mathbf{3}$ is the first catalytic precursor of osmium for the dehydrogenation of cyclic amines. Although this type of reactions is very sensitive to the experimental conditions and therefore the comparison with other metal systems should be carefully done, the results collected in Table 3 show that it can be a promising alternative to the classical catalysts, ${ }^{22-28}$ in particular to those of ruthenium with which molecular hydrogen releases between $0.16 \cdot 10^{-2}$ and $1.50 \cdot 10^{-2} \mathrm{~mol} \mathrm{~g}^{-1}$ have been achieved. $^{23}$

\section{CONCLUSIONS}

This study has revealed that the hydride ligands of the $d^{2}$ hexahydride $\mathrm{OsH}_{6}\left(\mathrm{P}^{\mathrm{i}} \mathrm{Pr}_{3}\right)_{2}$ are basic enough to deprotonate acetylacetone and to generate the classical trihydride $\mathrm{OsH}_{3}(\mathrm{acac})\left(\mathrm{P}^{\mathrm{i}} \mathrm{Pr}_{3}\right)_{2}$. This complex is useful to promote reactions of interest from an environmental point of view, which lead to imines and aromatic amines.

The formation of imines, including aliphatic ones, takes place by means of the catalytic dehydrogenation of alcohols and subsequent stoichiometric condensation of the resulting aldehyde or ketone with a primary amine. The procedure allows the preparation of a variety of products with yields between $90 \%$ and $40 \%$ after $1-48 \mathrm{~h}$, depending upon the nature of both alcohol and amine. The catalytic efficiency of $\mathrm{OsH}_{3}(\mathrm{acac})\left(\mathrm{P}^{\mathrm{i}} \mathrm{Pr}_{3}\right)_{2}$ is slightly lower than that of the very active tetrahydride $\mathrm{OsH}_{4}\left\{\kappa^{3}-\mathrm{POP}-\left[\mathrm{dbf}\left(\mathrm{P}^{\mathrm{i}} \mathrm{Pr}_{2}\right)_{2}\right]\right\}$. However, the former is a recommendable alternative to the latter, given the simplicity of its ligands and the speed and high yield of the procedure discovered for its preparation.

The aromatic amines have been generated by dehydrogenation of cyclic amines, being the trihydride $\mathrm{OsH}_{3}(\mathrm{acac})\left(\mathrm{P}^{\mathrm{i}} \mathrm{Pr}_{3}\right)_{2}$ the first catalytic precursor of osmium for this process. The trend of the substrates to undergo dehydro- genation increases as the space around the nitrogen atom also increases, which suggests that the coordination of the nitrogen atom to the metal center of the catalyst is the key step for the dehydrogenation. According to the amount of molecular hydrogen relelased by each gram of employed amine, the studied heterocycles can be classified into poor- $(1,2,3,4-$ tetrahydroquinaldine, 1-methylindoline, and 2,6dimethylpiperidine), moderate- (1,2,3,4-tetrahydroquinoline and 6-methyl-1,2,3,4-tetrahydroquinoline) and good-hydrogen donors (1,2,3,4-tetrahydroisoquinoline).

In conclusion, a new osmium-polyhydride, which is an efficient catalyst precursor for the formation of imines by acceptorless dehydrogenative coupling of alcohols and amines and for the dehydrogenation of cyclic amines to aromatic heterocycles, has been discovered.

\section{EXPERIMENTAL SECTION}

General Information. All reactions were carried out with rigorous exclusion of air using Schlenk-tube techniques. Solvents (except acetylacetone that was dried and distilled under argon) were obtained oxygen- and water-free from an MBraun solvent purification apparatus. ${ }^{1} \mathrm{H},{ }^{31} \mathrm{P}\left\{{ }^{1} \mathrm{H}\right\}$, and ${ }^{13} \mathrm{C}\left\{{ }^{1} \mathrm{H}\right\}$ NMR spectra were recorded on Bruker 300 ARX, Bruker Avance $300 \mathrm{MHz}$, and Bruker Avance 400 $\mathrm{MHz}$ instruments. Chemical shifts (expressed in parts per million) are referenced to residual solvent peaks $\left({ }^{1} \mathrm{H},{ }^{13} \mathrm{C}\left\{{ }^{1} \mathrm{H}\right\}\right)$, external 85\% $\mathrm{H}_{3} \mathrm{PO}_{4}\left({ }^{31} \mathrm{P}\left\{{ }^{1} \mathrm{H}\right\}\right)$, or external $\mathrm{CFCl}_{3}\left({ }^{19} \mathrm{~F}\left\{{ }^{1} \mathrm{H}\right\}\right)$. Coupling constants $J$ and $N$ are given in hertz. Attenuated total reflection infrared spectra (ATR-IR) of solid samples were run on a PerkinElmer Spectrum 100 FT-IR spectrometer. $\mathrm{C}$ and $\mathrm{H}$ analyses were carried out in a PerkinElmer $2400 \mathrm{CHNS} / \mathrm{O}$ analyzer. High-resolution electrospray mass spectra were acquired using a MicroTOF-Q hybrid quadrupole timeof-flight spectrometer (Bruker Daltonics, Bremen, Germany). Conductivities were measured in ca. $5 \times 10^{-4} \mathrm{M}$ acetone solutions of complexes 4 and 5 using a Philips PW 9501/01 conductimeter. $\mathrm{OsH}_{6}\left(\mathrm{P}^{\mathrm{i}} \mathrm{Pr}_{3}\right)_{2}$ (1) and $\mathrm{OsH}_{2} \mathrm{Cl}_{2}\left(\mathrm{P}^{\mathrm{i}} \mathrm{Pr}_{3}\right)_{2}$ (2) were prepared by the published methods. ${ }^{46 a}$ The formed imines were characterized by comparison of their ${ }^{1} \mathrm{H}$ NMR spectra with those reported previously $(\mathrm{N}$ benzylideneaniline, ${ }^{11} \quad N$-(4-chlorobenzylidene)aniline, ${ }_{53} N$-(1phenylethylidene)aniline, ${ }^{53} \mathrm{~N}$-phenylbenzophenone imine, ${ }_{11,55}^{54} \mathrm{~N}$ benzylidene- $p$-methylaniline, ${ }^{11} N$-benzyliden- $o$-methylaniline, ${ }^{11,55} \mathrm{~N}$ benzylidenebenzylamine, ${ }^{11,56,57} \mathrm{~N}$-benzylidenecyclohexylamine, ${ }^{11,55,57}$ $N$-benzylidenedodecylamine, ${ }^{11} \quad N$-cyclohexylmethylene- $p$ methylaniline, ${ }^{11} \quad \mathrm{~N}$-cyclohexylmethylenecyclohexylamine, ${ }^{11} \mathrm{~N}$ cyclohexylmethylenedodecylamine, ${ }^{11} N$-butylidene- $p$-methylaniline, ${ }^{58}$ $N$-butylidenecyclohexylamine, ${ }^{11}$ and $N$-butylidendodecylamine ${ }^{11}$ ).

Reaction of $\mathrm{OsH}_{6}\left(\mathrm{P}^{\mathrm{i}} \mathrm{Pr}_{3}\right)_{2}$ (1) with Acetylacetone: Preparation of $\mathbf{O s H}_{3}$ (acac)( $\left(\mathbf{P}^{\mathrm{i}} \mathbf{P r}_{3}\right)_{2}$ (3). Acetylacetone $(80 \mu \mathrm{L}, 0.78 \mathrm{mmol})$ was added to a solution of $1(200 \mathrm{mg}, 0.39 \mathrm{mmol})$ in toluene $(10 \mathrm{~mL})$ and heated under reflux for $1 \mathrm{~h}$, changing the color from colorless to bright yellow. The resulting solution was filtrated trough Celite and dried in vacuo, affording a yellow residue. Methanol $(3 \mathrm{~mL})$ was added to give a yellow solid, which was washed with further portions of methanol ( 2 x $1 \mathrm{~mL})$ and dried in vacuo. Yield: $197 \mathrm{mg}(83 \%)$. Anal. Calcd. for $\mathrm{C}_{23} \mathrm{H}_{52} \mathrm{O}_{2} \mathrm{OsP}_{2}$ : C, 45.08; H, 8.55. Found: C, 44.76; $\mathrm{H}, 8.48$. HRMS (electrospray, $m / z$ ) calcd for $\mathrm{C}_{23} \mathrm{H}_{51} \mathrm{O}_{2} \mathrm{OsP}_{2}[\mathrm{M}-\mathrm{H}]^{+}$: 613.2974; found: 613.2972. IR $\left(\mathrm{cm}^{-1}\right): v(\mathrm{Os}-\mathrm{H})$ 2137, $2101(\mathrm{~m})$; $v(\mathrm{C}=\mathrm{O}) 1588,1514(\mathrm{~s}) .{ }^{1} \mathrm{H}$ NMR $\left(400 \mathrm{MHz}, \mathrm{C}_{6} \mathrm{D}_{6}, 298 \mathrm{~K}\right): \delta 5.18(\mathrm{~s}$, $1 \mathrm{H}, \mathrm{CH}$ acac), 2.01 (m, 6H, $\left.\mathrm{PCH}\left(\mathrm{CH}_{3}\right)_{2}\right), 1.71$ (s, 6H, $\mathrm{CH}_{3}$ acac), 1.25 $\left(\mathrm{dvt},{ }^{3} J_{\mathrm{H}-\mathrm{H}}=6.5, N=12.6,36 \mathrm{H}, \mathrm{PCH}\left(\mathrm{CH}_{3}\right)_{2}\right),-12.83\left(\mathrm{t},{ }^{2} J_{\mathrm{H}-\mathrm{P}}=12.2\right.$, $3 \mathrm{H}, \mathrm{OsH}) .{ }^{1} \mathrm{H}\left\{{ }^{31} \mathrm{P}\right\}$ NMR $\left(400 \mathrm{MHz}\right.$, toluene- $d_{8}, 193 \mathrm{~K}$, high field region): $\delta-12.51\left(\mathrm{~d},{ }^{2} J_{\mathrm{H}-\mathrm{H}}=17.0,2 \mathrm{H}, \mathrm{OsH}\right),-13.14\left(\mathrm{t},{ }^{2} J_{\mathrm{H}-\mathrm{H}}=17.0\right.$, $1 \mathrm{H}, \mathrm{OsH}) .{ }^{13} \mathrm{C}\left\{{ }^{1} \mathrm{H}\right\}$ NMR $\left(100.63 \mathrm{MHz}, \mathrm{C}_{6} \mathrm{D}_{6}, 298 \mathrm{~K}\right): \delta 182.6(\mathrm{~s}$, $\mathrm{C}=\mathrm{O}$ acac), 101.4 (s, $\mathrm{CH}$ acac), 28.2 (s, $\mathrm{CH}_{3}$ acac), 27.3 (vt, $N=24.0$, $\left.\mathrm{PCH}\left(\mathrm{CH}_{3}\right)_{2}\right), 20.6\left(\mathrm{~s}, \mathrm{PCH}\left(\mathrm{CH}_{3}\right)_{2}\right) .{ }^{31} \mathrm{P}\left\{{ }^{1} \mathrm{H}\right\} \mathrm{NMR}\left(121.4 \mathrm{MHz}, \mathrm{C}_{6} \mathrm{D}_{6}\right.$, $298 \mathrm{~K}): \delta 36.6(\mathrm{~s}) . T_{1}(\mathrm{~min})\left(\mathrm{ms}, \mathrm{OsH}, 300 \mathrm{MHz}\right.$, toluene- $\left.d_{8}, 213 \mathrm{~K}\right)$ : $83 \pm 3(-12.54 \mathrm{ppm}), 53 \pm 3$ (-13.14 ppm).

Reaction of $\mathrm{OsH}_{3}(\mathrm{acac})\left(\mathrm{P}^{\mathrm{i}} \mathrm{Pr}_{3}\right)_{2}$ (3) with HOTf: Preparation of [OsH $\mathbf{O}_{2}$ (acac)(P'Pr $\mathbf{P r}_{2}$ ]OTf (4). A solution of 3 (150 mg, $\left.0.244 \mathrm{mmol}\right)$ 
in dichloromethane $(10 \mathrm{~mL})$ was treated with $\operatorname{HOTf}(22 \mu \mathrm{L}, 0.244$ $\mathrm{mmol})$ ) and stirred for $20 \mathrm{~min}$ at room temperature. The color of the solution changed from bright yellow to orange. The resulting solution was filtered through Celite and concentrated to ca. $0.5 \mathrm{~mL}$. Diethyl ether $(5 \mathrm{~mL})$ was added to afford a pale yellow solid, which was washed with further portions of diethyl ether $(3 \times 2 \mathrm{~mL})$ and dried in vacuo. Yield: $162 \mathrm{mg}(87 \%)$. Anal. Calcd. for $\mathrm{C}_{24} \mathrm{H}_{51} \mathrm{~F}_{3} \mathrm{O}_{5} \mathrm{OsP}_{2} \mathrm{~S}$ : C, 37.88; H, 6.76; S, 4.21. Found: C, 37.49; H, 6.89; S, 4.01. HRMS (electrospray, $m / z$ ) calcd for $\mathrm{C}_{23} \mathrm{H}_{51} \mathrm{O}_{2} \mathrm{OsP}_{2}[\mathrm{M}]^{+}:$: 613.2974; found: 613.2989. IR $\left(\mathrm{cm}^{-1}\right): v(\mathrm{Os}-\mathrm{H}) 2219(\mathrm{w}) ; \mathrm{v}(\mathrm{C}=\mathrm{O}) 1574,1528(\mathrm{~s}), v(\mathrm{C}-$ F) $1297, v(\mathrm{~S}-\mathrm{O}) 1229,1154,1023$ (vs). ${ }^{1} \mathrm{H} \mathrm{NMR}\left(300 \mathrm{MHz}, \mathrm{CD}_{2} \mathrm{Cl}_{2}\right.$, $298 \mathrm{~K}): \delta 6.22(\mathrm{~s}, 1 \mathrm{H}, \mathrm{CH}$ acac$), 2.32\left(\mathrm{~m}, 12 \mathrm{H}, \mathrm{PCH}\left(\mathrm{CH}_{3}\right)_{2}+\mathrm{CH}_{3}\right.$ acac), $1.28\left(\mathrm{dd},{ }^{3} J_{\mathrm{H}-\mathrm{H}}=7.2,{ }^{2} J_{\mathrm{H}-\mathrm{P}}=14.5,36 \mathrm{H}, \mathrm{PCH}\left(\mathrm{CH}_{3}\right)_{2}\right),-19.67(\mathrm{t}$, $\left.{ }^{2} J_{\mathrm{H}-\mathrm{P}}=34.7,2 \mathrm{H}, \mathrm{OsH}\right) .{ }^{13} \mathrm{C}\left\{{ }^{1} \mathrm{H}\right\} \mathrm{NMR}\left(75.4 \mathrm{MHz}, \mathrm{CD}_{2} \mathrm{Cl}_{2}, 298 \mathrm{~K}\right): \delta$ $189.8(\mathrm{~s}, \mathrm{C}=\mathrm{O}$ acac$), 121.5\left(\mathrm{q},{ }^{1} J_{\mathrm{C}-\mathrm{F}}=320.6, \mathrm{CF}_{3} \mathrm{SO}_{3}\right), 103.7(\mathrm{~s}, \mathrm{CH}$ acac), $28.6\left(\mathrm{~d},{ }^{1} J_{\mathrm{C}-\mathrm{P}}=34.5, \mathrm{PCH}\left(\mathrm{CH}_{3}\right)_{2}\right), 27.9\left(\mathrm{~s}, \mathrm{CH}_{3}\right.$ acac $), 19.5(\mathrm{~s}$, $\left.\mathrm{PCH}\left(\mathrm{CH}_{3}\right)_{2}\right) .{ }^{31} \mathrm{P}\left\{{ }^{1} \mathrm{H}\right\}$ NMR $\left(121.4 \mathrm{MHz}, \mathrm{CD}_{2} \mathrm{Cl}_{2}, 298 \mathrm{~K}\right): \delta 37.1$ (s). ${ }^{19} \mathrm{~F}\left\{{ }^{1} \mathrm{H}\right\}\left(282.3 \mathrm{MHz}, \mathrm{CD}_{2} \mathrm{Cl}_{2}, 298 \mathrm{~K}\right): \delta-78.8(\mathrm{~s}) . T_{1}(\mathrm{~min})(\mathrm{ms}, \mathrm{OsH}$, $\left.300 \mathrm{MHz}, \mathrm{CD}_{2} \mathrm{Cl}_{2}, 193 \mathrm{~K}\right): 211 \pm 6(-19.67 \mathrm{ppm}) . \Lambda_{\mathrm{M}}$ (acetone): 134 $\mathrm{ohm}^{-1} \mathrm{~cm}^{2} \mathrm{~mol}^{-1}$

Reaction of $\mathrm{OsH}_{2} \mathrm{Cl}_{2}\left(\mathrm{P}^{\mathrm{i}} \mathrm{Pr}_{3}\right)_{2}$ (2) with Acetylacetone: Preparation of $\mathrm{OsH}_{2} \mathbf{C l}$ (acac) $\left(\mathbf{P}^{\mathrm{i}} \mathbf{P r}_{3}\right)_{2}$ (5). A solution of 2 (100 mg, 0.17 $\mathrm{mmol})$ in acetylacetone $(5 \mathrm{~mL})$ was treated with 1 equiv of $\mathrm{KOH}(9.6$ $\mathrm{mg}, 0.17 \mathrm{mmol}$ ) and stirred for $5 \mathrm{~h}$ at room temperature. The color of the mixture changes quickly from brown to yellow. The resulting solution was filtered through Celite and evaporated to dryness. Pentane $(4 \mathrm{~mL})$ was added to afford a pale yellow solid, which was washed with further portions of pentane $(2 \times 1 \mathrm{~mL})$ and dried in vacuo. Yield: $78 \mathrm{mg}(64 \%)$. Anal. Calcd. for $\mathrm{C}_{23} \mathrm{H}_{51} \mathrm{ClO}_{2} \mathrm{OsP}_{2}$ : C, 42.68; H, 7.94. Found: C, 42.25; H, 7.89. HRMS (electrospray, $m / z$ ) calcd for $\mathrm{C}_{23} \mathrm{H}_{50} \mathrm{ClO}_{2} \mathrm{OsP}_{2}[\mathrm{M}-\mathrm{H}]^{+}$647.2574; found: 647.2619. IR $\left(\mathrm{cm}^{-1}\right)$ : v(Os-H) 2139, $2116(\mathrm{~m}) ; \mathrm{v}(\mathrm{C}=\mathrm{O}) 1587,1526(\mathrm{~s}) .{ }^{1} \mathrm{H}$ NMR $\left(300 \mathrm{MHz}, \mathrm{C}_{6} \mathrm{D}_{6}, 298 \mathrm{~K}\right): \delta 5.42(\mathrm{~s}, 1 \mathrm{H}, \mathrm{CH}$ acac$), 2.36(\mathrm{~m}, 6 \mathrm{H}$, $\left.\mathrm{PCH}\left(\mathrm{CH}_{3}\right)_{2}\right), 1.82\left(\mathrm{~s}, 6 \mathrm{H}, \mathrm{CH}_{3}\right.$ acac $), 1.24\left(\mathrm{dd}, J_{\mathrm{H}-\mathrm{H}}=7.2, J_{\mathrm{H}-\mathrm{P}}=12.4\right.$, $\left.36 \mathrm{H}, \mathrm{PCH}\left(\mathrm{CH}_{3}\right)_{2}\right),-12.77\left(\mathrm{t}, J_{\mathrm{H}-\mathrm{H}}=35.5,2 \mathrm{H}, \mathrm{OsH}\right) .{ }^{13} \mathrm{C}\left\{{ }^{1} \mathrm{H}\right\} \mathrm{NMR}$ $\left(100.63 \mathrm{MHz}, \mathrm{C}_{6} \mathrm{D}_{6}, 298 \mathrm{~K}\right): \delta 183.2$ (s, C=O), 100.9 (s, CH acac), $27.3\left(\mathrm{~d},{ }^{1} J_{\mathrm{C}-\mathrm{P}}=31.1, \mathrm{PCH}\left(\mathrm{CH}_{3}\right)_{2}\right), 27.1\left(\mathrm{~s}, \mathrm{CH}_{3}\right.$ acac$), 19.2(\mathrm{~s}$, $\left.\mathrm{PCH}\left(\mathrm{CH}_{3}\right)_{2}\right) .{ }^{31} \mathrm{P}\left\{{ }^{1} \mathrm{H}\right\}$ NMR $\left(121.4 \mathrm{MHz}, \mathrm{C}_{6} \mathrm{D}_{6}, 298 \mathrm{~K}\right): \delta 24.1$ (s). $T_{1}(\mathrm{~min})\left(\mathrm{ms}, \mathrm{OsH}, 300 \mathrm{MHz}\right.$, toluene- $\left.d_{8}, 223 \mathrm{~K}\right): 161 \pm 8(-12.77$ ppm). $\Lambda_{\mathrm{M}}$ (acetone): $1 \mathrm{ohm}^{-1} \mathrm{~cm}^{2} \mathrm{~mol}^{-1}$.

Reaction of $\mathrm{OsH}_{2} \mathrm{Cl}(\mathrm{acac})\left(\mathrm{P}^{\mathrm{i}} \mathrm{Pr}_{3}\right)_{2}$ (5) with AgOTF: Preparation of $\left.\left[\mathbf{O s H}_{2} \text { (acac)(P' } \mathbf{P r}_{3}\right)_{2}\right]$ OTf (4). AgOTf (40 mg, $\left.0.154 \mathrm{mmol}\right)$ dissolved in several drops of acetone was added to a $\mathrm{CH}_{2} \mathrm{Cl}_{2}$ solution (8 $\mathrm{mL})$ of 5 (100 mg, $0.154 \mathrm{mmol})$. After stirring for $1 \mathrm{~h}$ in the dark at room temperature, the resulting suspension was filtered through Celite to remove the silver salts. The solution thus resulting was concentrated to ca. $0.5 \mathrm{~mL}$, and diethyl ether $(5 \mathrm{~mL})$ was added to afford a pale yellow solid, which was washed with further portions of diethyl ether $(2 \times 2 \mathrm{~mL})$ and dried in vacuo. Yield: $80 \mathrm{mg}(68 \%)$.

Reaction of $\mathrm{OsH}_{2} \mathrm{Cl}(\mathrm{acac})\left(\mathrm{P}^{\mathrm{i}} \mathrm{Pr}_{3}\right)_{2}$ (5) with Acetylacetone: Preparation of $\mathbf{O s}(\mathbf{a c a c})_{2}\left(\mathbf{P}^{\mathrm{i}} \mathbf{P r}_{3}\right)_{2} \mathbf{( 6 )}$. A solution of $\mathbf{5}(100 \mathrm{mg}, 0.15$ $\mathrm{mmol})$ in acetylacetone $(5 \mathrm{~mL})$ was treated with 1 equiv of $\mathrm{KOH}(8.7$ $\mathrm{mg}, 0.15 \mathrm{mmol}$ ) and stirred for $4 \mathrm{~h}$ at room temperature, changing the color of the solution from yellow to dark red. The resulting solution was filtered through Celite and evaporated to dryness. Methanol was added to afford a dark red solid, which was washed with further portions of methanol and dried in vacuo. Yield: $22 \mathrm{mg}(20 \%)$. Anal. Calcd. for $\mathrm{C}_{28} \mathrm{H}_{56} \mathrm{O}_{4} \mathrm{OsP}_{2}$ : C, 47.44; H, 7.96. Found: C, 47.22; H, 7.77. HRMS (electrospray, $m / z$ ) calcd for $\mathrm{C}_{28} \mathrm{H}_{56} \mathrm{O}_{4} \mathrm{OsP}_{2}[\mathrm{M}]^{+}:$710.3264; found: 710.3292. IR $\left(\mathrm{cm}^{-1}\right): v(\mathrm{C}=\mathrm{O}) 1559,1509$ (s). ${ }^{1} \mathrm{H}$ NMR $(300$ $\left.\mathrm{MHz}, \mathrm{C}_{6} \mathrm{D}_{6}, 298 \mathrm{~K}\right): \delta 5.28(\mathrm{~s}, 2 \mathrm{H}, \mathrm{CH}$ acac $), 2.53(\mathrm{~m}, 6 \mathrm{H}$, $\left.\mathrm{PCH}\left(\mathrm{CH}_{3}\right)_{2}\right), 1.67$ (s, 6H, $\mathrm{CH}_{3}$ acac), 1.66 (s, 6H, $\left.\mathrm{CH}_{3} \mathrm{acac}\right), 1.37$ (dd, $\left.{ }^{3} J_{\mathrm{H}-\mathrm{H}}=7.1,{ }^{2} J_{\mathrm{H}-\mathrm{P}}=4.5,18 \mathrm{H}, \mathrm{PCH}\left(\mathrm{CH}_{3}\right)_{2}\right), 1.28\left(\mathrm{dd},{ }^{3} J_{\mathrm{H}-\mathrm{H}}=7.1,{ }^{2} J_{\mathrm{H}-\mathrm{P}}\right.$ $\left.=4.5,18 \mathrm{H}, \mathrm{PCH}\left(\mathrm{CH}_{3}\right)_{2}\right) \cdot{ }^{13} \mathrm{C}\left\{{ }^{1} \mathrm{H}\right\} \mathrm{NMR}\left(75.42 \mathrm{MHz}, \mathrm{C}_{6} \mathrm{D}_{6}, 298 \mathrm{~K}\right): \delta$ $183.5(\mathrm{~s}, \mathrm{C}=\mathrm{O}), 178.3(\mathrm{~s}, \mathrm{C}=\mathrm{O}), 102.4(\mathrm{~s}, \mathrm{CH}$ acac$), 30.1\left(\mathrm{~d},{ }^{1} J_{\mathrm{C}-\mathrm{P}}=\right.$ 27.1, $\left.\mathrm{PCH}\left(\mathrm{CH}_{3}\right)_{2}\right), 28.0,27.7$ (both s, $\mathrm{CH}_{3}$ acac), 20.6, 20.1 (both s, $\left.\mathrm{PCH}\left(\mathrm{CH}_{3}\right)_{2}\right) .{ }^{31} \mathrm{P}\left\{{ }^{1} \mathrm{H}\right\}$ NMR $\left(121.4 \mathrm{MHz}, \mathrm{C}_{6} \mathrm{D}_{6}, 298 \mathrm{~K}\right): \delta-12.2$ (s).

Catalyst Optimization. A solution of the chosen catalyst $(0.0163$ $\mathrm{mmol})$, potassium hydroxide $(0.081 \mathrm{mmol})$, aniline $(1.63 \mathrm{mmol})$, and benzyl alcohol $(1.63 \mathrm{mmol})$ in toluene $(1 \mathrm{~mL})$ was placed in a schlenk flask equipped with a Dean-Stark apparatus and a condenser. The mixture was stirred at the reflux temperature in an open system for 1 h. After cooling at room temperature it was evaporated under reduced pressure to obtain an oil, which was analyzed by ${ }^{1} \mathrm{H}$ NMR spectroscopy

General Procedure for the $\mathrm{OsH}_{3}(\mathrm{acac})\left(\mathrm{P}^{\mathrm{i}} \mathrm{Pr}_{3}\right)_{2}$ (3) Catalyzed $\mathrm{N}$ alkylation of Amines with Alcohols. A solution of $3(0.0163 \mathrm{mmol})$ potassium hydroxide $(0.081 \mathrm{mmol})$ and the corresponding substrates $(1.63 \mathrm{mmol})$ in toluene $(1 \mathrm{~mL})$ was placed in a schlenk flask equipped with a Dean-Stark apparatus and a condenser. The mixture was stirred at the reflux temperature in an open system for the specified time (Table 2). After cooling at room temperature it was evaporated under reduced pressure to obtain an oil. Then, $0.815 \mathrm{mmol}(52 \mu \mathrm{L})$ of dichloromethane was added as an internal standard. The mixture was dissolved in $\mathrm{CDCl}_{3}$, and was transferred to a $2 \mathrm{~mL}$ volumetric flask. Afterwards, $0.5 \mathrm{~mL}$ of this solution was analyzed by ${ }^{1} \mathrm{H}$ NMR spectroscopy. The formed imines were characterized by ${ }^{1} \mathrm{H}$ NMR spectroscopy.

General Procedure for the $\mathrm{OsH}_{3}(\mathrm{acac})\left(\mathrm{P}^{\mathrm{i}} \mathrm{Pr}_{3}\right)_{2}$ (3) Catalyzed Dehydrogenation Reactions of Cyclic Amines. A solution of complex $3(0.0163 \mathrm{mmol})$ and the corresponding substrate $(0.163 \mathrm{mmol})$ in $p$-xylene $(1 \mathrm{~mL})$ was placed in a schlenk flask equipped with a condenser. The mixture was stirred at $140{ }^{\circ} \mathrm{C}$ for $48 \mathrm{~h}$. After this time the solution was cooled to room temperature, and the progress of the reaction was monitored by GC on a Hewlett-Packard 5890 series II gas chromatograph with a flame ionization detector, using a $100 \%$ cross-linked methyl silicone gum column $(30 \mathrm{~m} \times 0.32 \mathrm{~mm}$, with 0.25 $\mu \mathrm{m}$ film thickness). The oven conditions used are as follows: $80{ }^{\circ} \mathrm{C}$ (hold $1 \mathrm{~min}$ ) to $220^{\circ} \mathrm{C}$ at $10^{\circ} \mathrm{C} / \mathrm{min}$ (hold $2 \mathrm{~min}$ ).

Structural Analysis of Complexes 3 and 6. The cif files of $\mathbf{3}$ and 6 have been deposited with the Cambridge Crystallographic Data Center (Nos. CCDC 1547645 (3) and 1547646 (6)). X-ray data were collected for the complexes on a Bruker Smart APEX CCD DUO (3) or Bruker Smart APEX CCD (6) diffractometers equipped with a normal focus, $2.4 \mathrm{~kW}$ sealed tube source (Mo radiation, $\lambda=0.71073$ $\AA$ ) operating at $50 \mathrm{kV}$ and $30 \mathrm{~mA}$. Data were collected over the complete sphere. Each frame exposure time was $10 \mathrm{~s}$ (covering $0.3^{\circ}$ in $\omega$ ). Data were corrected for absorption by using a multiscan method applied with the SADABS program. ${ }^{59}$ The structures were solved by Patterson or direct methods and refined by full-matrix least squares on $\mathrm{F}^{2}$ with SHELXL 2016/6, ${ }^{60}$ including isotropic and subsequently anisotropic displacement parameters. The hydrogens not bonded to the osmium atoms were observed in the least Fourier Maps or calculated, and refined freely or using a restricted riding model. The hydrogens bonded to metal atoms were observed in the last cycles of refinement but refined too close to metals, so a restricted refinement model was used for all of them $(\mathrm{d}(\mathrm{Os}-\mathrm{H})=1.59(1) \AA)$

Crystal data for 3: $\mathrm{C}_{23} \mathrm{H}_{52} \mathrm{O}_{2} \mathrm{OsP}_{2}$, mol wt 612.78 , yellow, irregular block $(0.190 \times 0.161 \times 0.122 \mathrm{~mm})$, triclinic, space group $\mathrm{P}-1, a$ : 8.9802(10) $\AA, b: 11.8374(13) \AA, c: 14.3966(16) \AA, a: 73.9350(10)^{\circ}$, $\beta: 87.117(2)^{\circ}, \gamma: 68.2470(10)^{\circ}, V=1363.6(3) \AA^{3}, Z=2, Z^{\prime}=1, \mathrm{D}_{\text {calc }}$ : $1.492 \mathrm{~g} \mathrm{~cm}^{-3}, \mathrm{~F}(000): 624, \mathrm{~T}=100(2) \mathrm{K}, \mu=4.808 \mathrm{~mm}^{-1} .15084$ measured reflections $\left(2 \theta: 3-58^{\circ}, \omega\right.$ scans $\left.0.3^{\circ}\right), 6894$ unique reflections $\left(\mathrm{R}_{\mathrm{int}}=0.0222\right) ;$ minimun/maximun transmission factors $0.723 / 0.862$. Final agreement factors were $\mathrm{R}^{1}=0.0197$ (6520 observed reflections, $\mathrm{I}>2 \sigma(\mathrm{I}))$ and $\mathrm{wR}^{2}=0.0481$; data/restraints/parameters 6894/3/276; GoF $=1.029$. Largest peak and hole were 1.383 (close to the osmium atom) and $-0.820 \mathrm{e} / \AA^{3}$.

Crystal data for 6: $\mathrm{C}_{28} \mathrm{H}_{56} \mathrm{O}_{4} \mathrm{OsP}_{2}$, mol wt 708.86, red, irregular block $(0.174 \times 0.126 \times 0.113 \mathrm{~mm})$, monoclinic, space group $\mathrm{P} 2{ }_{1} / \mathrm{n}, a$ : $10.6019(4) \AA, b: 19.7066(7) \AA, c: 15.3908(6) \AA, \beta: 98.7460(4)^{\circ}, V=$ $3178.2(2) \AA^{3}, Z=4, Z^{\prime}=1, \mathrm{D}_{\text {calc }}: 1.481 \mathrm{~g} \mathrm{~cm}^{-3}, \mathrm{~F}(000): 1448, \mathrm{~T}=$ $100(2) \mathrm{K}, \mu=4.142 \mathrm{~mm}^{-1} .26297$ measured reflections $\left(2 \theta: 3-58^{\circ}, \omega\right.$ scans $\left.0.3^{\circ}\right), 7557$ unique reflections $\left(\mathrm{R}_{\text {int }}=0.0218\right)$; minimun/maximun transmission factors $0.723 / 0.863$. Final agreement factors were $\mathrm{R}^{1}=0.0215$ (7019 observed reflections, $\left.\mathrm{I}>2 \sigma(\mathrm{I})\right)$ and $\mathrm{wR}^{2}=0.0523$; data/restraints/parameters 7557/0/332; GoF $=1.034$. Largest peak and hole were 1.713 (close to the osmium atom) and $0.908 \mathrm{e} / \AA^{3}$

\section{ASSOCIATED CONTENT}




\section{Supporting Information}

The Supporting Information is available free of charge on the ACS Publications website.

${ }^{1} \mathrm{H},{ }^{13} \mathrm{C}\left\{{ }^{1} \mathrm{H}\right\}$ APT, ${ }^{31} \mathrm{P}\left\{{ }^{1} \mathrm{H}\right\}$, and ${ }^{19} \mathrm{~F}\left\{{ }^{1} \mathrm{H}\right\}$ NMR spectra of complexes 3-6, ${ }^{1} \mathrm{H}$ NMR spectra of the reaction mixtures of the acceptorless dehydrogenative coupling of alcohols and amines and computational details (pdf).

Cartesian coordinates of computed 3 (XYZ).

\section{AUTHOR INFORMATION}

\section{Corresponding Author}

* E-mail for M.A.E.: maester@unizar.es

Notes

The authors declare no competing financial interest.

\section{ACKNOWLEDGMENT}

Financial support from the MINECO of Spain (Projects CTQ2014-52799-P and CTQ2016-81797-REDC), the Diputación General de Aragón (E-35), FEDER, and the European Social Fund is acknowledged.

\section{REFERENCES}

(1) (a) Trost, B. M. Science 1991, 254, 1471-1477. (b) Trost, B. M. Angew. Chem. Int. Ed. 1995, 34, 259-281. (c) Trost, B. M. Acc. Chem. Res. 2002, 35, 695-705.

(2) (a) Friedrich, A.; Schneider, S. ChemCatChem 2009, 1, 72-73. (b) Johnson, T. C.; Morris, D. J.; Wills, M. Chem. Soc. Rev. 2010, 39, 81-88. (c) Choi, J.; MacArthur, A. H. R.; Brookhart, M.; Goldman, A. S. Chem. Rev. 2011, 111, 1761-1779. (d) Gunanathan, C.; Milstein, D. Science 2013, 341, 1229712. (e) Werkmeister, S.; Neumann, J.; Junge, K.; Beller, M. Chem. Eur. J. 2015, 21, 12226-12250. (f) Nielsen, M. Hydrogen Production by Homogeneous Catalysis: Alcohol Acceptorless Dehydrogenation. In Hydrogen Production and Remediation of Carbon and Pollutants; Lichtfouse, E.; Schwarzbauer, J.; Robert, D., Eds.; Springer, 2015; pp 1-60. (g) Ventura-Espinosa, D.; Mata, J. A. Eur. J. Inorg. Chem. 2016, 2667-2675.

(3) The Hydrogen Economy: Opportunities, Costs, Barriers and R\&D Needs; National Academic Press: Washington, DC, 2004.

(4) See for example: (a) Murahashi, S. I. Angew. Chem. Int. Ed. Engl. 1995, 34, 2443-2465. (b) Murahashi, S. I.; Imada, I. in Transition Metals for Organic Synthesis; Beller, M.; Bolm, C., Eds; vol. 2, $2^{\text {nd }}$ ed; Wiley-VCH, Weinheim 2004, pp 497-507. (c) Martin, S. F. Pure Appl. Chem. 2009, 81, 195-204. (d) Gawronski, J.; Wascinska, N.; Gajewy, J. Chem. Rev. 2008, 108, 5227-5252.

(5) See for example: (a) Kobayashi, S.; Ishitani, H. Chem. Rev. 1999, 99, 1069-1094. (b) Adams, J. P. J. Chem. Soc., Perkin Trans. 1 2000, 125-139. (c) Kobayashi, S.; Mori, Y.; Fossey, J. S.; Salter, M. M. Chem. Rev. 2011, 111, 2626-2704. (d) Yus, M.; Gónzalez-Gómez, J. C.; Foubelo, F. Chem. Rev. 2011, 111, 7774-7854. (e) Yus, M.; Gónzalez-Gómez, J. C.; Foubelo, F. Chem. Rev. 2013, 113, 55955698.

(6) See for example: (a) Liu, G.; Cogan, D. A.; Owens, T. D.; Tang, T. P.; Ellman, J. A. J. Org. Chem. 1999, 64, 1278-1284. (b) Naeimi, H.; Salimi, F.; Rabiei, K. J. Mol. Catal. A: Chem. 2006, 260, 100-104. (c) Reeves, J. T.; Visco, M. D.; Marsini, M. A.; Grinberg, N.; Busacca, C. A.; Mattson, A. E.; Senanayake, C. H. Org. Lett. 2015, 17, 2442-2445.

(7) See for example: (a) Schümperli, M. T.; Hammond, C.; Hermans, I. ACS Catal. 2012, 2, 1108-1117. (b) Largeron, M. Eur. J. Org. Chem. 2013, 5225-5235. (c) Ray, R.; Chandra, S.; Yadav, V.; Mondal, P.; Maiti, D.; Lahiri, G. K. Chem. Commun. 2017, 53, 40064009.

(8) Chen, B.; Wang, L.; Gao, S. ACS Catal. 2015, 5, 5851-5876.

(9) Müller, T. E.; Hultzsch, K. C.; Yus, M.; Foubelo, F.; Tada, M. Chem. Rev. 2008, 108, 3795-3892.

(10) Gnanaprakasam, B.; Zhang, J.; Milstein, D. Angew. Chem. Int. Ed. 2010, 49, 1468-1471.
(11) Esteruelas, M. A.; Honczek, N.; Oliván, M.; Oñate, E.; Valencia, M. Organometallics 2011, 30, 2468-2471.

(12) (a) Zeng, G.; Li, S. Inorg. Chem. 2011, 50, 10572-10580. (b) Maggi, A.; Madsen, R. Organometallics 2012, 31, 451-455. (c) Li, H., Wang, X.; Wen, M.; Wang, Z.-X. Eur. J. Inorg. Chem. 2012, 5011-5020. (d) Rigoli, J. W.; Moyer, S. A.; Pearce, S. D.; Schomaker, J. M. Org. Biomol. Chem. 2012, 10, 1746-1749. (e) Nakajima, Y.; Okamoto, Y.; Chang, Y.-H.; Ozawa, F. Organometallics 2013, 32, 2918-2925. (f) Musa, S.; Fronton, S.; Vaccaro, L.; Gelman, D. Organometallics 2013, 32, 3069-3073. (g) Srimani, D.; Ben-David, Y.; Milstein, D. Angew. Chem. Int. Ed. 2013, 52, 4012-4015. (h) Saha, B.; Rahaman, S. M. W.; Daw, P.; Sengupta, G.; Bera, J. K. Chem. Eur. J. 2014, 20, 6542-6551. (i) Oldenhuis, N. J.; Dong, V. M.; Guan, Z. Tetrahedron 2014, 70, 4213-4218.

(13) Mukherjee, A.; Nerush, A.; Leitus, G.; Shimon, L. J. W.; Ben David, Y.; Espinosa Jalapa N. A.; Milstein, D. J. Am. Chem. Soc. 2016, 138, 4298-4301.

(14) Jaiswal, G.; Landge, V. G.; Jagadeesan, D.; Balaraman, E. Green Chem. 2016, 18, 3232-3238.

(15) Zhang, G.; Hanson, S. K. Org. Lett. 2013, 15, 650-653.

(16) Xu, C.; Goh, L. Y.; Pullarkat, S. A. Organometallics 2011, 30, 6499-6502.

(17) Lee, S.-H.; Nikonov, G. I. Chem CatChem 2015, 7, 107-113.

(18) Kim, D.; Kang, B.; Hong, S. H. Org. Chem. Front. 2016, 3, 475-479.

(19) Eberle, U.; Felderhoff, M.; Schüth, F. Angew. Chem. Int. Ed. 2009, 48, 6608-6630.

(20) (a) Trincado, M.; Banerjee, D.; Grützmacher, H. Energy Environ. Sci. 2014, 7, 2464-2503. (b) Giustra, Z. X.; Ishibashi, J. S. A.; Liu, S.-Y. Coord. Chem. Rev. 2016, 314, 134-181. (c) Preuster, P.; Papp, C.; Wasserscheid, P. Acc. Chem. Res. 2017, 50, 74-85.

(21) Crabtree, R. H. Energy Environ. Sci. 2008, 1, 134-138.

(22) (a) Chakraborty, S.; Brennessel, W. W.; Jones, W. D. J. Am. Chem. Soc. 2014, 136, 8564-8567. (b) Zhou, W.; Taboonpong, P.; Aboo, A. H.; Zhang, L.; Jiang, J.; Xiao, J. Synlett 2016, 27, 18061809.

(23) (a) Tsuji, Y.; Kotachi, S.; Huh, K.-T.; Watanabe, Y. J. Org. Chem. 1990, 55, 580-584. (b) Muthaiah, S.; Hong, S. H. Adv. Synth. Catal. 2012, 354, 3045-3053. (c) Tseng, K.-N. T.; Rizzi, A. M.; Szymczak, N. K. J. Am. Chem. Soc. 2013, 135, 16352-16355. (d) Stubbs, J. M.; Hazlehurst, R. J.; Boyle, P. D.; Blacquiere, J. M. Organometallics 2017, 36, 1692-1698.

(24) Xu, R.; Chakraborty, S.; Yuan, H.; Jones, W. D. ACS Catal. 2015, 5, 6350-6354.

(25) (a) Wang, Z.; Tonks, I.; Belli, J.; Jensen, C. M. J. Organomet. Chem. 2009, 694, 2854-2857. (b) Yamaguchi, R.; Ikeda, C.; Takahashi, Y.; Fujita, K. J. Am. Chem. Soc. 2009, 131, 8410-8412. (c) Li, H.; Jiang, J.; Lu, G.; Huang, F.; Wang, Z.-X. Organometallics 2011, 30, 3131-3141. (d) Zhang, X.-B.; Xi, Z. Phys. Chem. Chem. Phys. 2011, 13, 3997-4004. (e) Wu, J.; Talwar, D.; Johnston, S.; Yan, M.; Xiao, J. Angew. Chem. Int. Ed. 2013, 52, 6983-6987. (f) Fujita, K.; Tanaka, Y.; Kobayashi, M.; Yamaguchi, R. J. Am. Chem. Soc. 2014, 136, 4829-4832. (g) Manas, M. G.; Sharninghausen, L. S.; Lin, E.; Crabtree, R. H. J. Organomet. Chem. 2015, 792, 184-189. (h) Talwar, D.; Gonzalez-de-Castro, A.; Li, H. Y.; Xiao, J. Angew. Chem. Int. Ed. 2015, 54, 5223-5227. (i) Wang, C.; Xiao, J. Chem. Commun. 2017, 53, 3399-3411.

(26) Luca, O. R.; Huang, D. L.; Takase, M. K.; Crabtree, R. H. New J. Chem. 2013, 37, 3402-3405.

(27) Hara, T.; Mori, K.; Mizugaki, T.; Ebitani, K.; Kaneda, K. Tetrahedron Lett. 2003, 44, 6207-6210.

(28) (a) Mikami, Y.; Ebata, K.; Mitsudome, T.; Mizugaki, T.; Jitsukawa, K.; Kaneda, K. Heterocycles 2011, 82, 1371-1377. (b) Damodara, D.; Arundhathi, R.; Likhar, P. R. Adv. Synth. Catal. 2014, 356, 189-198.

(29) Esteruelas, M. A.; López, A. M.; Oliván, M. Chem. Rev. 2016, $116,8770-8847$.

(30) (a) Borowski, A. F.; Sabo-Etienne, S.; Donnadieu, B.; Chaudret, B. Organometallics 2003, 22, 4803-4809. (b) Prechtl, M. H. G.; Hölscher, M.; Ben-David, Y.; Theyssen, N.; Loschen, R.; Milstein, D.; Leitner, W. Angew. Chem. Int. Ed. 2007, 46, 2269-2272. 
(c) Caballero, A.; Sabo-Etienne, S. Organometallics 2007, 26, 11911195. (d) Reguillo, R.; Grellier, M.; Vautravers, N.; Vendier, L.; Sabo-Etienne, S. J. Am. Chem. Soc. 2010, 132, 7854-7855.

(31) Esteruelas, M. A.; Oro, L. A. Chem. Rev. 1998, 98, 577-588.

(32) See for example: (a) Lu, X. Y.; Lin, Y. Q. G.; Ma, D. W. Pure Appl. Chem. 1988, 60, 1299-1306. (b) Ma, D.; Lu, X. Tetrahedron Lett. 1989, 30, 2109-2112. (c) Lin, Y.; Zhu, X.; Zhou, Y. A. J. Organomet. Chem. 1992, 429, 269-274. (d) Park, S.; Brookhart, M. J. Am. Chem. Soc. 2012, 134, 640-653.

(33) Rossin, A.; Peruzzini, M. Chem. Rev. 2016, 116, 8848-8872.

(34) Bertoli, M.; Choualeb, A.; Gusev, D. G.; Lough, A. J.; Major, Q.; Moore, B. Dalton Trans. 2011, 40, 8941-8949.

(35) Bianchini, C.; Farnetti, E.; Graziani, M.; Peruzzini, M.; Polo, A. Organometallics 1993, 12, 3753-3761.

(36) Esteruelas, M. A.; Oro, L. A.; Valero, C. Organometallics 1992, $11,3362-3369$

(37) Esteruelas, M. A.; López, A. M.; Mora, M.; Oñate, E. ACS Catal. 2015, 5, 187-191.

(38) (a) Esteruelas, M. A.; Sola, E.; Oro, L. A.; Werner, H.; Meyer, U. J. Mol. Catal. 1988, 45, 1-5. (b) Esteruelas, M. A.; Sola, E.; Oro, L. A.; Werner, H.; Meyer, U. J. Mol. Catal. 1989, 53, 43-52. (c) Esteruelas, M. A.; Valero, C.; Oro, L. A.; Meyer, U.; Werner, H. Inorg. Chem. 1991, 30, 1159-1160.

(39) (a) Werner, H.; Meyer, U.; Esteruelas, M. A.; Sola, E.; Oro, L. A. J. Organomet. Chem. 1989, 366, 187-196. (b) Espuelas, J.; Esteruelas, M. A.; Lahoz, F. J.; Oro, L. A.; Valero, C. Organometallics 1993, 12, 663-670.

(40) Esteruelas, M. A.; Herrero, J.; López, A. M.; Oliván, M. Organometallics 2001, 20, 3202-3205.

(41) Alós, J.; Bolaño, T.; Esteruelas, M. A.; Oliván, M.; Oñate, E.; Valencia, M. Inorg. Chem. 2013, 52, 6199-6213.

(42) (a) Baya, M.; Eguillor, B.; Esteruelas, M. A.; Oliván, M.; Oñate, E. Organometallics 2007, 26, 6556-6563. (b) Eguillor, B.; Esteruelas, M. A.; Oliván, M.; Puerta, M. Organometallics 2008, 27 , 445-450. (c) Alabau, R. G.; Eguillor, B.; Esler, J.; Esteruelas, M. A.; Oliván, M.; Oñate, E.; Tsai, J.-Y.; Xia, C. Organometallics 2014, 33, 5582-5596. (d) Bolaño, T.; Esteruelas, M. A.; Fernández, I.; Oñate, E.; Palacios, A.; Tsai, J.-Y.; Xia, C. Organometallics 2015, 34, 778789. (e) Bolaño, T.; Esteruelas, M. A.; Gay, M. P.; Oñate, E.; Pastor, I. M.; Yus, M. Organometallics 2015, 34, 3902-3908. (f) Alabau, R. G.; Esteruelas, M. A.; Oliván, M.; Oñate, E.; Palacios, A. U.; Tsai, J.Y.; Xia, C. Organometallics 2016, 35, 3981-3995. (g) Eguillor, B.; Esteruelas, M. A.; Lezáun, V.; Oliván, M.; Oñate, E.; Tsai, J.-Y.; Xia, C. Chem. Eur. J. 2016, 22, 9106-9110.

(43) (a) Esteruelas, M. A.; Lahoz, F. J.; López, A. M.; Oñate, E.; Oro, L. A.; Ruiz, N.; Sola, E.; Tolosa, J. I. Inorg. Chem. 1996, 35, 7811-7817. (b) Castillo, A.; Barea, G.; Esteruelas, M. A.; Lahoz, F. J.; Lledós, A.; Maseras, F.; Modrego, J.; Oñate, E.; Oro, L. A.; Ruiz, N.; Sola, E. Inorg. Chem. 1999, 38, 1814-1824. (c) Esteruelas, M. A.; García-Raboso, J.; Oliván, M.; Oñate, E. Inorg. Chem. 2012, 51, 5975-5984. (d) Esteruelas, M. A.; García-Raboso, J.; Oliván, M. Inorg. Chem. 2012, 51, 9522-9528. (e) Casarrubios, L.; Esteruelas, M. A.; Larramona, C.; Muntaner, J. G.; Oliván, M.; Oñate, E.; Sierra, M. A. Organometallics 2014, 33, 1820-1833. (f) Eguillor, B.; Esteruelas, M. A.; Fernández, I.; Gómez-Gallego, M.; Lledós, A.; Martín-Ortiz, M.; Oliván, M.; Oñate, E.; Sierra, M. A. Organometallics 2015, 34, 1898-1910.

(44) (a) Esteruelas, M. A.; Lahoz, F. J.; Lopez, J. A.; Oro, L. A.; Schlünken, C.; Valero, C.; Werner, H. Organometallics 1992, 11, 2034-2043. (b) Barrio, P.; Esteruelas, M. A.; Oñate, E. Organometallics 2004, 23, 1340-1348. (c) Eguillor, B.; Esteruelas, M. A.; GarcíaRaboso, J.; Oliván, M.; Oñate, E.; Pastor, I. M.; Peñafiel, I.; Yus, M. Organometallics 2011, 30, 1658-1667. (d) Esteruelas, M. A.; GarcíaRaboso, J.; Oliván, M. Organometallics 2011, 30, 3844-3852.

(45) The total relaxation rate for a $\mathrm{H}_{(\mathrm{n})}$ hydride ligand $\left(R_{(\mathrm{n})}=\right.$ $\left.1 / T_{1}(\min )_{\mathrm{H}(\mathrm{n})}\right)$ is the addition of the relaxation rate due to the hydride dipole-dipole interaction (at $300 \mathrm{MHz} R_{\mathrm{H}-\mathrm{H}}=129.8 / r_{(\mathrm{HH})}{ }^{6}$ ) and that due to all other relaxation contributors $\left(R^{*}\right)$. See: Jessop, P. G.; Morris, R. H. Coord. Chem. Rev. 1992, 121, 155-284. Thus, in this case, one can obtain the separation between the hydride ligands by using the equation system: $R_{\mathrm{Ht}}=R^{*}+R_{\mathrm{Ht}}{ }^{-H c} ; R_{\mathrm{Hc}}=R^{*}+2 R_{\mathrm{Ht}}{ }^{-H c}$.
(46) (a) Aracama, M.; Esteruelas, M. A.; Lahoz, F. J.; López, J. A. Meyer, U.; Oro, L. A.; Werner, H. Inorg. Chem. 1991, 30, 288-293. (b) Atencio, R.; Esteruelas, M. A.; Lahoz, F. J.; Oro, L. A.; Ruiz, N. Inorg. Chem. 1995, 34, 1004-1006. (c) Kuhlman, R.; Streib, W. E.; Huffman, J. C.; Caulton, K. G. J. Am. Chem. Soc. 1996, 118, 69346945. (d) Wolf, J.; Stuer, W.; Grünwald, C.; Gevert, O.; Laubender, M.; Werner, H. Eur. J. Inorg. Chem. 1998, 1827-1834. (e) Battacharya, S.; Gupta, P.; Basuli, F.; Pierpont, C. G. Inorg. Chem. 2002, 41, 5810-5816. (f) Baya, M.; Esteruelas, M. A.; Oñate, E. Organometallics 2011, 30, 4404-4408.

(47) Crochet, P.; Esteruelas, M. A.; López, A. M.; Martínez, M.-P.; Oliván, M.; Oñate, E.; Ruiz, N. Organometallics 1998, 17, 45004509.

(48) Tolman, C. A. Chem. Rev. 1977, 77, 313-348.

(49) Buil, M. L.; Esteruelas, M. A.; García-Yebra, C.; GutiérrezPuebla, E.; Oliván, M. Organometallics 2000, 19, 2184-2193.

(50) (a) Grünwald, C., Laubender, M.; Wolf, J.; Werner, H. J. Chem. Soc., Dalton Trans. 1998, 833-839. (b) Bennett, M. A.; Byrnes, M. J.; Chung, G.; Edwards, A. J.; Willis, A. C. Inorg. Chim. Acta 2005, 358, 1692-1708

(51) (a) Dam, J. H.; Osztrovszky, G.; Nordstrøm, L. U.; Madsen, R. Chem. Eur. J. 2010, 16, 6820-6827. (b) Kang, B.; Fu, Z.; Hong, S. H. J. Am. Chem. Soc. 2013, 135, 11704-11707.

(52) Bennett, J. S.; Charles, K. L.; Miner, M. R.; Heuberger, C. F.; Spina, E. J.; Bartels, M. F.; Foreman, T. Green Chem. 2009, 11, 166168

(53) Shirai, S.; Nara, H.; Kayaki, Y.; Ikariya, T. Organometallics 2009, 28, 802-809.

(54) Liu, S.; Yu, Y.; Liebeskind, L. S. Org. Lett. 2007, 9, 19471950.

(55) Jiang, L.; Jin, L.; Tian, H.; Yuan, X.; Yu, X.; Xu, Q. Chem. Commun. 2011, 47, 10833-10835.

(56) Zhang, G.; Hanson, S. K. Org. Lett. 2013, 15, 650-653.

(57) Mukherjee, A.; Nerush, A.; Leitus, G.; Shimon, L. J. W.; Ben David, Y.; Espinosa Jalapa N. A.; Milstein, D. J. Am. Chem. Soc. 2016, $138,4298-4301$

(58) Mastalir, M.; Glatz, Gorgas, N.; Stöger, B.; Pittenauer, E.; Allmaier, G.; Veiros, L. F.; Kirchner, K. Chem. Eur. J. 2016, 22, 12316-12320.

(59) Blessing, R. H. Acta Crystallogr. 1995, A51, 33-38. SADABS: Area-detector absorption correction; Bruker- AXS, Madison, WI, 1996.

(60) SHELXL 2016/6; Sheldrick, G. M. Acta Cryst. 2008, A64, $112-122$. 


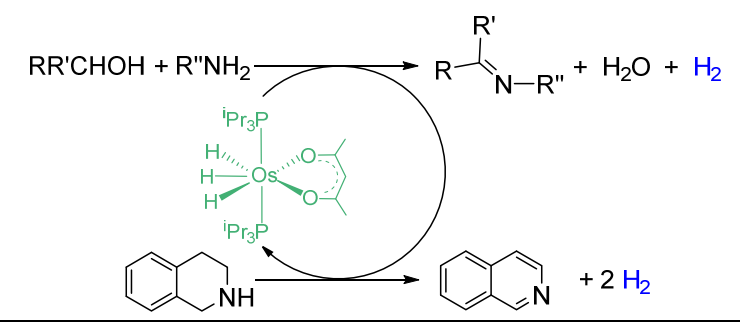

